\title{
Integrated Action of Mixture Rates and Nitrogen Levels on Quantity and Quality of Forage Mixture from Egyptian Clover and Barley in Sandy Soil
}

\author{
Mohamed Farouk El-Karamany, Bakry Ahmed Bakry, Tarek Abd El-Fattah Elewa \\ Field Crops Research Department, National Research Centre, Giza, Egypt \\ Email: bakry ahmed2004@yahoo.com
}

Received 25 October 2014; revised 16 November 2014; accepted 2 December 2014

Copyright (C) 2014 by authors and Scientific Research Publishing Inc.

This work is licensed under the Creative Commons Attribution International License (CC BY). http://creativecommons.org/licenses/by/4.0/

\section{(c) (i) Open Access}

\begin{abstract}
Effect of seeding rate mixture from Egyptian clover (Trifolium alexandrinum L.) E.C. and barley (Hordum vulgare L.) B, N-fertilization levels and their interaction on quantity and quality of forage yield. Two field experiments were conducted during winter season of 2012/2013 and 2013/2014 in sandy soil at research and production station of National Research Centre, Al Nubaria district, Al Behaira Governorate, Egypt. The experiment included two factors first was five mixtures from seeding rates $(24 \mathrm{~kg}$ EC/fed. $-50 \mathrm{~kg} \mathrm{~B} /$ fed. $-18 \mathrm{~kg} \mathrm{EC}+12.5 \mathrm{~kg} \mathrm{~B} /$ fed. $-12 \mathrm{~kg} \mathrm{EC}+25 \mathrm{~kg} \mathrm{~B} / \mathrm{fed}$. -6 $\mathrm{kg} \mathrm{EC}+37.5 \mathrm{~kg} \mathrm{~B} / \mathrm{fed}$.) and second factor was three $\mathrm{N}$ levels (30-45-60 kg N/fed.). Two cuts were obtained at 60 and 100 DAS. Results indicated significant differences between mixture rates for all studied characters in both cuts 60 and 100 DAS. Significant differences between N levels for all studied characters at 60 DAS, also, forage yield /fed. and DM\% at 100 DAS. It can be introducing forage mixture of $18 \mathrm{~kg}$ EC +12.5 B had balanced character in forage yield/fed., DM\%, carbohydrate $\%$ and protein $\%$ at both cuts 60 and 100 DAS.
\end{abstract}

\section{Keywords}

Forage Mixture, Egyptian Clover, Barley, N-Levels

\section{Introduction}

Egyptian clover is the first forage crop under Egyptian condition; its cultivated area was 1.07 million hectare/ year FAOSTAT (2012). Although it gave high forage yield and high protein \% in forage the dry matter is low. 
Legume-cereal mixtures is low input technology has many useful effects on quantity and quality of forage mixture. It gave high forage yield with high protein content from legume plus high DM\% and carbohydrates\% from cereal which reflect on quantity and quality of forage mixture. [1]-[3] stated the benefits of intercropping of (legume-cereal). [4]-[7] reported that the amount of fertilizer $\mathrm{N}$ needed for optimum DM and protein yield depends upon the \% of legume in the grass-legume mixture, soil-climatic characteristics of the region, and the prevailing economic conditions. [8] stated that barley, oat and triticale were comparable to clover re-growth and [9] stated that grass-legume mixtures increased forage yield than sole forage crop either grass or legume. [10] found that stage of maturity at harvest is the most important factor determining the yield and quality of a cereal crop when used as forage and the maximum yield of energy per unit area will occur when the cereal is at the soft dough stage of development. [11] concluded that crop mixtures clearly have many advantages and are superior to monocultures, providing greater yield and quality stability and better exploiting all the resources available through enhanced crop plasticity. [12] pointed that relative performance of any mixture was dependent on when it was harvested, increased $\mathrm{N}$ fertilizer application may be a means to improve protein content. [13] reported that grasses, when grown in association with legumes, may utilize some $\mathrm{N}$ fixed by legumes resulting in improved forage DM and protein yield. [14] stated that intercropping barley with Australian winter pea may increase the use efficiencies of growth resources and reduce fertilizer $\mathrm{N}$ requirements. $\mathrm{N}$ fertilizer increased total biomass yield and protein level in barley-pea intercrops, but high $\mathrm{N}$ rates could decrease the LER and equivalent ratio. [15] [16] clear that increasing clover stand in mixture of (legume-cereal) clover and triticale or barley or oat increased forage yield and quality. [17] pointed that barley is potentially promising crop component in the some legume-cereal mixtures for forage and hay production during winter period under rain fed condition. [18] concluded that addition of a red clover (Trifolium pretense L.) intercrop to winter cereal grains can supply forage and provide $\mathrm{N}$ to subsequent crops. [19] [20] reported superiority of first cut at 60 DAS in forage yield, superiority of clover in forage yield and protein $\%$ followed by mixture of $75 \%$ clover $+25 \%$ triticale but sole barley recorded the best DM\% and carbohydrates\% followed by $25 \%$ clover $+75 \%$ barley, also, pointed that seeding rate mixture of $80 \%$ Egyptian clover $+20 \%$ triticale produced mixture identify $79 \%$ forage yield, $99 \%$ protein, $73 \% \mathrm{DM}$ and $65 \%$ carbohydrates from best treatment in each character so, they recommended it to be promise mixture.

\section{Materials and Methods}

Two field experiments were carried out during winter season of 2012/2013 and 2013/2014 at researches and production station of National Research Centre, Al Nubaria district, Al Behaira Governorate, Egypt. The experimental soil was analyzed according to [21]. Soil texture was sandy and its characteristics are shown in Table 1.

Experimental soil ploughed twice and divided to plots $3 \times 7 \mathrm{~m}$, then made rows $20 \mathrm{~cm}$ between. Egyptian clover cultivar (Meskawy) was inoculated with the appropriate (Rhizobium trifolii) in a commercial product produced by Ministry of Agriculture, Egypt; barley Giza-123 cultivar was seeded by broadcasting on the surface and incorporated at rows $20 \mathrm{~cm}$ row spacing by raking.

\subsection{Treatments Were Interactions between Two Factors}

\subsubsection{Mixture Seeding Rates as Follow}

1) $100 \%$ sole Egyptian clover (EC) at rate $24 \mathrm{~kg}$ clover/fed. (recommended seeding rate)

2) $100 \%$ sole barley (B) at rate $50 \mathrm{~kg}$ barley/fed. (recommended seeding rate)

3) $75 \%(\mathrm{EC})+25 \%(\mathrm{~B})=(18 \mathrm{~kg}$ clover $+12.5 \mathrm{~kg}$ barley $/$ fed. $)$

4) $50 \%$ (EC) $+50 \%$ (B) $=(12 \mathrm{~kg}$ clover $+25 \mathrm{~kg}$ barley/fed. $)$

5) $25 \%(\mathrm{EC})+75 \%$ (B) $=(6 \mathrm{~kg}$ clover $+37.5 \mathrm{~kg}$ barley/fed. $)$

\subsubsection{N Fertilizer Rates as Follow}
1) $30 \mathrm{~kg} \mathrm{~N} / \mathrm{fed}$.
2) $45 \mathrm{~kg} \mathrm{~N} / \mathrm{fed}$.
3) $60 \mathrm{~kg} \mathrm{~N} / \mathrm{fed}$.

The experimental design was randomized complete block design in four replicates.

Sowing dates were first week of October in both 1st and 2nd seasons. Plots were irrigated before and after 
Table 1. Mechanical and chemical analysis of experimental soil.

\begin{tabular}{cccccccccc}
\hline $\begin{array}{c}\text { Sand } \\
\%\end{array}$ & $\begin{array}{c}\text { Silt } \\
\%\end{array}$ & $\begin{array}{c}\text { Clay } \\
\%\end{array}$ & $\mathrm{pH}$ & $\begin{array}{c}\text { Organic } \\
\text { matter, } \%\end{array}$ & $\begin{array}{c}\mathrm{CaCO}_{3} \\
\%\end{array}$ & $\begin{array}{c}\text { E.C. } \\
\text { dS/m }\end{array}$ & $\begin{array}{c}\text { Soluble N, } \\
\text { ppm }\end{array}$ & $\begin{array}{c}\text { Available } \\
\text { P, ppm }\end{array}$ & $\begin{array}{c}\text { Exchangeable } \\
\text { K, ppm }\end{array}$ \\
\hline 91.2 & 3.7 & 5.1 & 7.3 & 0.3 & 1.4 & 0.3 & 8.1 & 3.2 & 20 \\
\hline
\end{tabular}

seeding by sprinkler method according to district system. Plots were hand weeded at 21 days after sowing DAS. Fertilization of NPK (66:31:24) kg/fed. were add to all treatments, P31 in the form of calcium super phosphate $15.5 \% \mathrm{P}_{2} \mathrm{O}_{5}$ incorporated with soil before seeding, $\mathrm{N} 66$ in the form of ammonium nitrate $33 \% \mathrm{~N}$ in 5 portions at seeding date; 21 DAS; 40 DAS; 60 DAS = after $1^{\text {st }}$ cut; 90 DAS after $2^{\text {nd }}$ cut. K 24 in the form of potassium sulfate $48 \% \mathrm{~K}_{2} \mathrm{O}$ in three portions at seeding date, after $1^{\text {st }}$ and $2^{\text {nd }}$ cut.

The first cut was taken at (milk to soft dough) stage of barley 60 DAS by hand cutting at 5 to $10 \mathrm{~cm}$ above soil level, 2nd cut at $90 \mathrm{DAS}$. Total forage of each plot were taken to determine forage yield ton/fed. Sub sample of $0.5 \mathrm{~m} \times 0.5 \mathrm{~m}=0.25 \mathrm{~m}^{2}$ weighted as fresh and dried at $72^{\circ} \mathrm{C}$ and weighted to determine DM\% for all treatments. Nitrogen was determined by kjeldahl method and multiplied by 6.25 for crude protein according to [22]. Total carbohydrates in forage were determined by method described by [23].

The obtained results were subjected to statistical analysis of variance according to method described by [24] since the trend was similar in both seasons the homogeneity test Bartlett's equation was applied and the combined analysis of the two seasons was calculated according to the method [25].

One Feddan $=$ fed. $=4200 \mathrm{~m}^{2}$; DAS $=$ days after sowing .

\section{Results and Discussion}

Data presented in Tables 2-7 show effect of seeding rates of either pure stand or mixtures between Egyptian clover (legume) and barley (cereal) at $1^{\text {st }}$ and $2^{\text {nd }}$ cuts at 60 and 100 DAS in 2012/2013 and 2013/2014 seasons. Quantity and quality of forage mixture as affected by different seeding rates show significant differences between treatments for all studied characters.

\subsection{Effect of Mixture Rates}

\subsubsection{Forage Yield (ton/fed.)}

It is clear from data in Table 2, Table 3 and Figure 1, Figure 2 that treatments of clover pure stand produced the highest forage yield 22.61 and 20.84 (ton/fed.) in both cuts 60 and 100 DAS. Mixture of $18 \mathrm{~kg}$ clover/fed. + $12.5 \mathrm{~kg}$ barley/fed. produced the second forage yield 17.93 and 18.51 ton/fed. in both cuts followed by pure stand of barley at 60 DAS and $12 \mathrm{~kg}$ clover $+25 \mathrm{~kg}$ barley/fed. at 100 DAS. Superiority of legume pure stand in forage yield over mixtures of legume-cereal at any mixture rates recorded by many researchers [5]-[7] [15] [16] [19] and [20].

\subsubsection{Dry Matter \%}

Pure stand of barley gave the best DM\% at 60 DAS but mixture of $6 \mathrm{~kg}$ clover $+37.5 \mathrm{~kg}$ barley/fed. was the best at 100 DAS, decreasing barley \% in mixture decrease DM\% in mixture at 60 and 100 DAS, sole clover recorded the lowest DM\% in forage in both cuts. These results were in accordance with those obtained by [11], also, [19] [20] reported nearly result on clover-triticale.

\subsubsection{Carbohydrates \%}

Clover + barley $(6 \mathrm{~kg}+37.5 \mathrm{~kg} /$ fed.) treatment produced mixture contain highest carbohydrates \% followed by pure stand of barley at 60 DAS then decreasing barley in the mixture from 37.5 to 25 to $12.5 \mathrm{~kg} / \mathrm{fed}$. decrease carbohydrates \% in forage mixture and the lowest carbohydrates \% recorded by sole clover. The same trend was true at 100 DAS although sole barley came in the first order and clover + barley (6 kg + $37.5 \mathrm{~kg} / \mathrm{fed}$.) was second.

\subsubsection{Protein \%}

The data in Table 4, Table 5 and Figure 3, Figure 4 showed that treatment of pure stand of clover produced the highest protein \%, decreasing clover in mixture from 18-12-6 kg/fed. decrease protein \% in forage mixture at 60 and 100 DAS, sole barley recorded the lowest protein \% in both cuts. Results were in accordance with obtained 
Table 2. Effect of mixture rates on quantity and quality of forage mixture of Egyptian clover (Trifolium alexandrinum L.) with barley (Hordum vulgare L.) under newly reclaimed sandy soil at $60 \mathrm{DAS}$-combined of two seasons.

\begin{tabular}{ccccc}
\hline Treatments & Forage Yield (ton/fed.) & Dry Matter \% & Carbohydrates \% & Protein \% \\
\hline Clover (24 kg/fed.) & 22.61 & 10.78 & 16.55 & 15.00 \\
Barley (50 kg/fed.) & 17.14 & 15.55 & 23.46 & 6.73 \\
Clover + Barley (18 kg + 12.5 kg/fed.) & 17.93 & 12.01 & 17.77 & 6.98 \\
Clover + Barley (12 kg + 25 kg/fed.) & 17.8 & 12.47 & 17.82 & 7.27 \\
Clover + Barley (6 kg + 37.5 kg/fed.) & 15.75 & 15.22 & 23.71 & 8.08 \\
LSD 0.05 & 2.51 & 0.532 & 0.59 & 0.44 \\
\hline
\end{tabular}

Table 3. Effect of mixture rates on quantity and quality of forage mixture of Egyptian clover (Trifolium alexandrinum L.) with barley (Hordum vulgare L.) under newly reclaimed sandy soil at 100 DAS.

\begin{tabular}{ccccc}
\hline Treatments & Forage Yield (ton/fed.) & Dry Matter \% & Carbohydrates \% & Protein \% \\
\hline Clover (24 kg/fed.) & 20.84 & 10.37 & 16.34 & 15.53 \\
Barley (50 kg/fed.) & 12.84 & 14.37 & 23.40 & 7.28 \\
Clover + Barley (18 kg + 12.5 kg/fed.) & 18.51 & 11.48 & 17.45 & 7.43 \\
12 kg Clover + 25 kg Barley & 15.92 & 11.71 & 17.14 & 7.46 \\
6 kg Clover + 37.5 kg Barley & 12.04 & 14.41 & 23.01 & 7.90 \\
LSD 0.05 & 1.83 & 0.253 & 0.778 & 0.493 \\
\hline
\end{tabular}

Table 4. Effect of $\mathrm{N}$ fertilization on quantity and quality of forage mixture of Egyptian clover (Traifolium alexandrinum L.) with barley (Hordum vulgare L.) under newly reclaimed sandy soil at 60 DAS. Combined of two seasons.

\begin{tabular}{ccccc}
\hline Treatments & Forage Yield (ton/fed.) & DM \% & Carbohydrates \% & Protein \% \\
\hline $30 \mathrm{~kg} \mathrm{~N} /$ fed & 18.63 & 13.24 & 19.52 & 8.42 \\
$45 \mathrm{~kg} \mathrm{~N} /$ fed & 16.83 & 12.91 & 19.94 & 8.84 \\
$60 \mathrm{~kg} \mathrm{~N} /$ fed & 20.48 & 13.47 & 20.16 & 9.15 \\
LSD 0.05 & 1.95 & 0.41 & 0.46 & 0.34 \\
\hline
\end{tabular}

Table 5. Effect of nitrogen fertilization on quantity and quality of forage mixture of Egyptian clover (Traifolium alexandrinum L.) with barley (Hordum vulgare L.) under newly reclaimed sandy soil at 100 DAS. Combined of two seasons.

\begin{tabular}{ccccc}
\hline Treatments & Forage yield/fed. & Dry Matter \% & Carbohydrates \% & Protein \% \\
\hline 30 kg N/fed. & 17.34 & 12.64 & 19.48 & 19.22 \\
45 kg N/fed. & 15.06 & 11.89 & 19.68 & 9.12 \\
60 kg N/fed. & 17.02 & 12.88 & 9.22 & ns \\
LSD 0.05 & 1.416 & 0.506 & ns \\
\hline
\end{tabular}

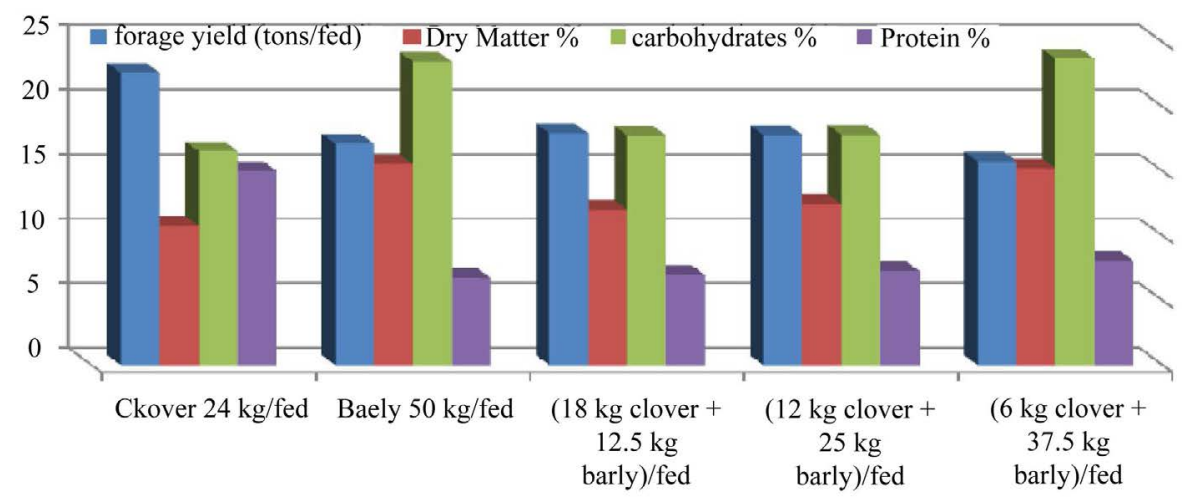

Figure 1. Effect of Mixture rates on quantity and quality of forage mixture of Egyptian clover with barley under newly reclaimed sandy soil at 60 DAS. 


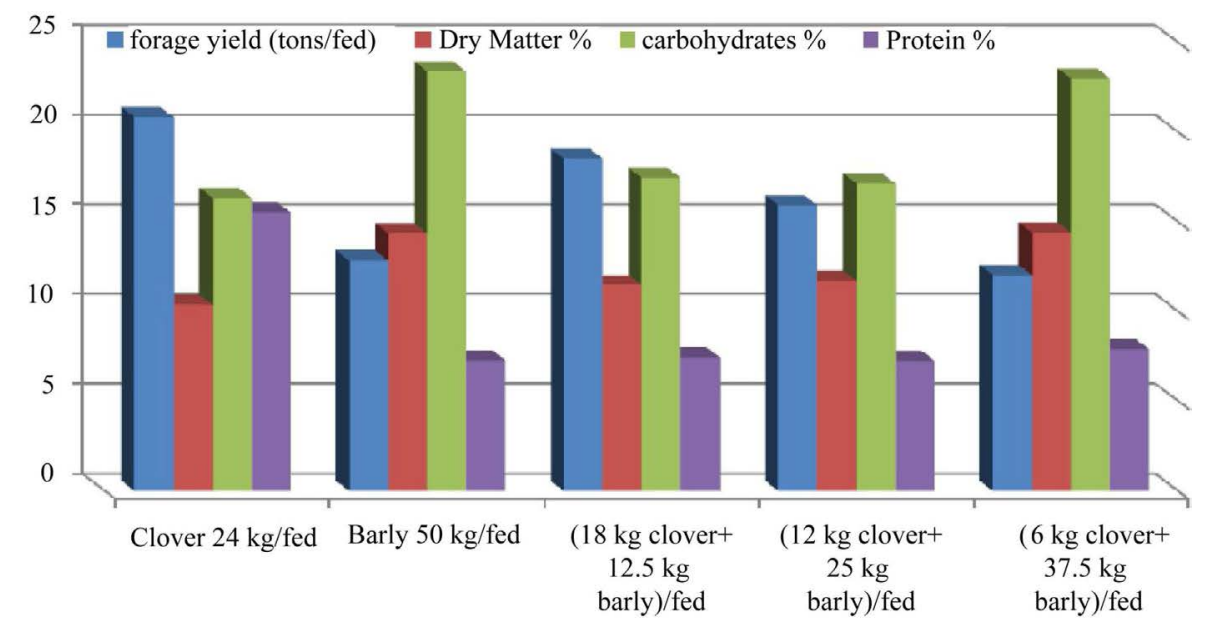

Figure 2. Effect of mixture rates on quantity and quality of forage mixture of Egyptian clover (Traifolium alexandrinum L.) with barley (Hordum vulgare L.) under newly reclaimed sandy soil at 100 DAS.

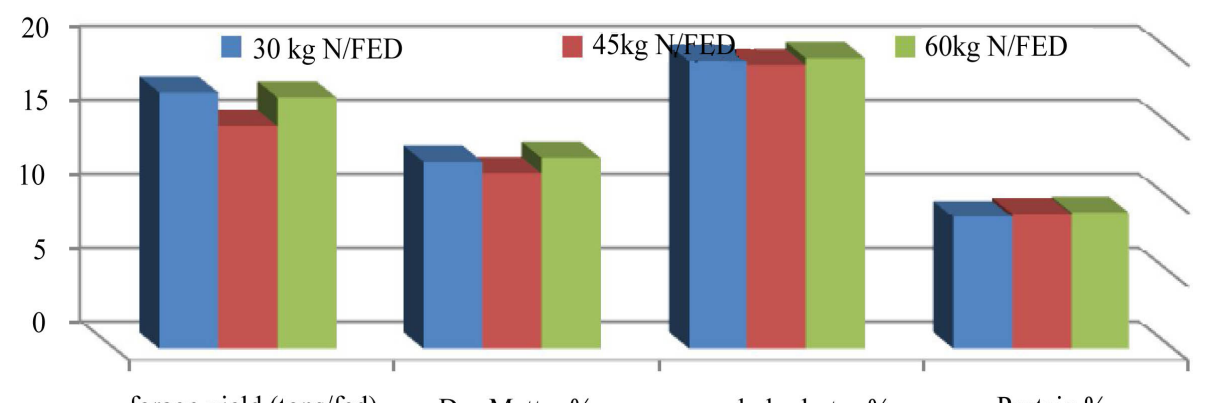

forage yield (tons/fed) Dry Matter $\%$

carbohydrates \%

Protein \%

Figure 3. Effect of nitrogen fertilization on quantity and quality of forage mixture of Egyptian clover with barley under newly reclaimed sandy soil at 60 DAS.

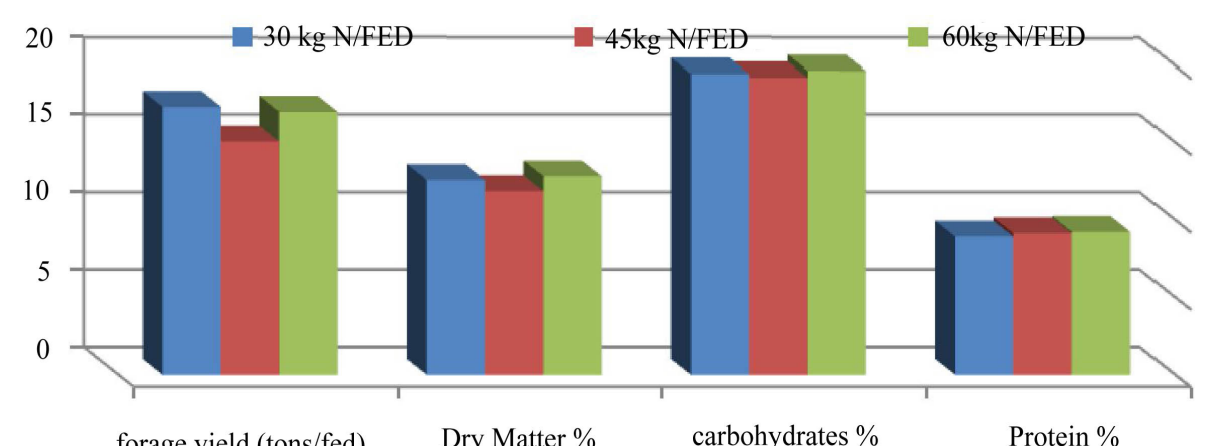

Figure 4. Effect of nitrogen fertilization on quantity and quality of forage mixture of Egyptian clover with barley under newly reclaimed sandy soil at 100 DAS.

by [13] [19] [20].

\subsection{N-Fertilizer}

Data presented in Table 4, Table 5 and Figure 2 show significant differences between three rates of $\mathrm{N}$ fertilizer in all studied characters in both cuts except for carbohydrates \% and protein \% at 100 DAS differences are insignificant. 
Table 6. Effect of Mixture rates and nitrogen fertilization on quantity and quality of forage mixture of Egyptian clover (Traifolium alexandrinum L.) with barley (Hordum vulgare L.) under newly reclaimed sandy soil at 60 DAS.

\begin{tabular}{|c|c|c|c|c|c|}
\hline & Treatments & Forage yield/fed. & Dry Matter \% & Carbohydrates \% & Protein \% \\
\hline \multirow{6}{*}{30 kg N/fed. } & Clover 24 kg & 21.66 & 10.86 & 16.16 & 14.6 \\
\hline & Barley 50 kg & 17.86 & 15.86 & 22.8 & 6.53 \\
\hline & 18 kg Clover + 12.5 kg Barley & 19.8 & 11.93 & 17.5 & 6.3 \\
\hline & 12 kg Clover + 25 kg Barley & 17.36 & 12.8 & 17.5 & 7.16 \\
\hline & 6 kg Clover + 37.5 kg Barley & 16.46 & 14.66 & 23.53 & 7.53 \\
\hline & Clover 24 kg & 21.86 & 10.2 & 16.53 & 15.1 \\
\hline \multirow{3}{*}{45 kg N/fed. } & Barley 50 kg & 14.86 & 15.27 & 23.76 & 6.73 \\
\hline & 18 kg Clover + 12.5 kg Barley & 18.46 & 11.86 & 17.8 & 7.33 \\
\hline & 12 kg Clover + 25 kg Barley & 16.2 & 12.07 & 17.76 & 7.3 \\
\hline \multirow{7}{*}{$60 \mathrm{~kg} \mathrm{~N} /$ fed. } & 6 kg Clover + 37.5 kg Barley & 12.66 & 15.16 & 23.86 & 8 \\
\hline & Clover 24 kg & 24.3 & 11.3 & 16.96 & 15.3 \\
\hline & Barley 50 kg & 18.6 & 15.3 & 23.83 & 6.93 \\
\hline & 18 kg Clover + 12.5 kg Barley & 22.53 & 12.2 & 17.96 & 7.63 \\
\hline & 12 kg Clover + 25 kg Barley & 19.83 & 12.56 & 18.16 & 7.36 \\
\hline & 6 kg Clover + 37.5 kg Barley & 18.13 & 15.83 & 23.73 & 8.53 \\
\hline & LSD 0.05 & 0.68 & 0.82 & 0.48 & 0.52 \\
\hline
\end{tabular}

Table 7. Effect of mixture rates and nitrogen fertilization on quantity and quality of forage mixture of Egyptian clover (Traifolium alexandrinum L.) with barley (Hordum vulgare L.) under newly reclaimed sandy soil at 100 DAS.

\begin{tabular}{|c|c|c|c|c|c|}
\hline & Treatments & Forage yield/fed. & Dry Matter \% & Carbohydrates \% & Protein \% \\
\hline \multirow{6}{*}{30 kg N/fed. } & Clover 24 kg & 23.46 & 10.56 & 15.9 & 15 \\
\hline & Barley 50 kg & 13.66 & 15.2 & 24.3 & 6.95 \\
\hline & 18 kg Clover + 12.5 kg Barley & 19 & 11.13 & 17.36 & 7.3 \\
\hline & 12 kg Clover + 25 kg Barley & 17 & 12.06 & 16.9 & 7.4 \\
\hline & 6 kg Clover + 37.5 kg Barley & 13.6 & 14.23 & 22.96 & 7.9 \\
\hline & Clover 24 kg & 22.06 & 10.3 & 16.06 & 15.7 \\
\hline \multirow{3}{*}{45 kg N/fed. } & Barley 50 kg & 12 & 13.2 & 23.13 & 7.6 \\
\hline & 18 kg Clover + 12.5 kg Barley & 16.3 & 11.2 & 17.13 & 7 \\
\hline & 12 kg Clover + 25 kg Barley & 14.3 & 10.8 & 17 & 7.3 \\
\hline \multirow{7}{*}{60 kg N/fed. } & 6 kg Clover + 37.5 kg Barley & 10.63 & 13.96 & 22.8 & 8 \\
\hline & Clover 24 kg & 23.66 & 10.26 & 17 & 15.9 \\
\hline & Barley 50 kg & 12.86 & 14.73 & 22.76 & 7.3 \\
\hline & 18 kg Clover + 12.5 kg Barley & 22.26 & 12.13 & 17.86 & 8 \\
\hline & 12 kg Clover + 25 kg Barley & 16.43 & 12.26 & 17.53 & 7.1 \\
\hline & 6 kg Clover + 37.5 kg Barley & 11.9 & 15.03 & 23.26 & 7.8 \\
\hline & LSD 0.05 & 1.04 & 0.6 & 0.56 & 0.42 \\
\hline
\end{tabular}

\subsubsection{Forage Yield (ton/fed.)}

The data in Table 4, Table 5 and Figure 3, Figure 4 showed that treatments of $60 \mathrm{~kg} /$ fed. N-fertilizer produced the best forage yield 20.48 ton/fed. followed by $30 \mathrm{~kg} / \mathrm{fed}$. and $45 \mathrm{~kg} / \mathrm{fed}$. was third in both cuts, result in accordance with [4]-[7] [14].

\subsubsection{Dry Matter \%}

Data presented in Table 4, Table 5 and Figure 3, Figure 4 show that treatment of $60 \mathrm{~kg} / \mathrm{fed}$. N-fertilizer gave the best DM \% in forage mixture followed by $30 \mathrm{~kg} \mathrm{~N} / \mathrm{fed}$. and $45 \mathrm{~kg} / \mathrm{fed}$. was third in both cuts, it is the same trend in forage yield/fed. [13] recorded same result. 


\subsubsection{Carbohydrates \%}

Results indicated that at 60 DAS increasing $\mathrm{N}$-fertilizer from 30 to 45 to $60 \mathrm{~kg} /$ fed. increase carbohydrates in forage mixture in ascending order 19.52-19.94-20.16. But at 100 DAS $60 \mathrm{~kg} / \mathrm{fed}$. came first followed by 30 $\mathrm{kg} / \mathrm{fed}$. then $45 \mathrm{~kg} / \mathrm{fed}$.

\subsubsection{Protein \%}

Increasing $\mathrm{N}$-fertilizer from 30 to 45 to $60 \mathrm{~kg} /$ fed. increased protein content in forage mixture at 60 and 100 DAS, the same result was obtained by [13].

\subsection{Interaction of Mixture Rates and N-Fertilizer Rates}

Table 6 and Table 7 show that there were significant differences between interactions in all studied characters in both cuts 60 and 100 DAS. Due to forage yield/fed. interaction of clover pure stand $\times 60 \mathrm{~kg} \mathrm{~N}$-fertilizer was the best at both cuts 60 and 100 DAS as logic trend. Interaction of $18 \mathrm{~kg}$ clover $+12.5 \mathrm{~kg}$ barley recorded the second order in both cuts.

There were inconstant trend due to other characters pure stand of barley fertilized by $30 \mathrm{~kg} \mathrm{~N} /$ fed. produced the highest DM\% in both cuts followed by $6 \mathrm{~kg}$ clover $+37.5 \mathrm{~kg}$ barley $\times 60 \mathrm{kgN} / \mathrm{fed}$. The highest carbohydrates\% recorded by interaction of $6 \mathrm{~kg}$ clover $+37.5 \mathrm{~kg}$ barley $\times 45 \mathrm{~kg} \mathrm{~N} / \mathrm{fed}$. and sole barley $50 \mathrm{~kg} \times 60 \mathrm{~kg}$ $\mathrm{N} /$ fed at 60DAS but sole barley $\times 30 \mathrm{~kg} \mathrm{~N} / \mathrm{fed}$. was the best and $6 \mathrm{~kg}$ clover $+37.5 \mathrm{~kg}$ barley/fed. was second at 100 DAS. Sole clover at the rate of $24 \mathrm{~kg} / \mathrm{fed} . \times 60 \mathrm{~kg} \mathrm{~N} / \mathrm{fed}$. produced the highest protein\% followed by pure stand clover $\times 45 \mathrm{~kg} \mathrm{~N} / \mathrm{fed}$.

\section{Conclusion}

Superiority of pure stand clover in forage yield/fed. and protein \% and superiority of sole barley in DM\% and carbohydrates \%, also, superiority of $\mathrm{N}$-fertilizer rate $60 \mathrm{~kg} / \mathrm{fed}$ on $45 \mathrm{~kg} / \mathrm{fed}$. and $30 \mathrm{~kg} / \mathrm{fed}$. is logical trend. There was inconstant trend due to interactions between seeding mixture and $\mathrm{N}$-fertilizer rates thus, researchers recommend conducting animal feeding trails to examine response of animals to these interactions.

\section{References}

[1] Bayoumi, M.A. and Rahman, A.H. (1982) Forage Yield and Nutritive Content of Barley Sown Alone and in Mixtures with Vetch and Egyptian Clover. The Libyan Journal of Agriculture, 11, 75-86.

[2] Hussein, T.A. and El-Latif, L.I.A. (1982) Effect of Mixed Sowing of Berseem (Trifolium alexandrinum L.) and Barley (Hordeum vulgare L.) on the Green Fodder, Dry Matter and Seed Yield of Berseem. Annals of Agricultural Science, Moshtohor Journal, 18, 27-36.

[3] Osman, A.E. and Nersoyan, N. (1985) Annual Legumes for Integrating Rainfed Crop and Livestock Production. Proceeding xv. International Grassland Congers, 5, 123-125.

[4] Campbell, C.A., Leyshon, A.J., Ukrainetz, H. and Zentner, R.P. (1986) Time of Application and Source of N-Fertilizer on Yield, Quality, N Recovery and Net Return for Dry Land Forage Grasses. Canadian Journal of Plant Science, 66, 915-931. http://dx.doi.org/10.4141/cjps86-114

[5] Malhi, S.S. and Nyborg, M. (1986) Encrease in Mineral N in Soils during Winter and Loss of Mineral N during Early Spring in North-Central Alberta. Canadian Journal of Soil Science, 66, 397-409. http://dx.doi.org/10.4141/cjss86-042

[6] Malhi, S.S., Baron, V.S. and McBeath, D.K. (1987) Economics of N Fertilization of Bromegrass for Hay in Central Alberta. Canadian Journal of Plant Science, 67, 1105-1109. http://dx.doi.org/10.4141/cjps87-149

[7] Zentner, R.P., Ukrainetz, H. and Campbell, C.A. (1989) The Economics of Fertilizing Bromegrass in the Saskatchewan. Canadian Journal of Plant Science, 69, 841-859. http://dx.doi.org/10.4141/cjps89-100

[8] Ghaffarzadeh, M. (1997) Economic and Biological Benefits of Intercropping Berseem Clover with Oat in Corn-SoybeanOat Rotations. Journal of Production Agriculture, 10, 314-319. http://dx.doi.org/10.2134/jpa1997.0314

[9] Tukel, T., Hasar, E. and Hatipoglu, R. (1997) Effect of Mixture Rates and Cutting Dates on the Forage Yield and Quality of Vetch-Triticale Mixtures and Their Seed Yields under Lowland Conditions of Cukurova, XVIII. International Grasslands Congress, Saskatoon, 8-19 June 1997, 25-26.

[10] Johnston, J., Wheeler, B. and McKinlay, J. (1998) Forage Production from Spring Cereals and Cereal-Pea Mixtures. Ontario, Ministry of Agriculture Food \& Rural Affairs (OMAF), Ontario. http://www.omafra.gov.on.ca/english/crops/facts/98-041.htm 
[11] Habernichit, D.K. and Blake, T.K. (1999) Crop Mixtures. Journal of American Society of Brewing Chemistry, 57, 6471.

[12] Juskiw, P.E., Helm, J.H. and Salmon, D.F. (2000) Forage Yield and Quality for Monocrops and Mixtures of Small Grain Cereals. Crop Science, 40, 138-147. http://dx.doi.org/10.2135/cropsci2000.401138x

[13] Malhi, S.S., Zentner, R.P. and Heier, K. (2002) Effectiveness of Alfalfa in Reducing Fertilizer N Input for Optimum Forage Yield, Protein Concentration, Returns and Energy Performance of Bromegrass-Alfalfa Mixtures. Nutrient Cycling in Agroecosystems, 62, 219-227. http://dx.doi.org/10.1023/A:1021229824357

[14] Chen, C.C., Westcott, M., Neill, K., Wichman, D. and Knox, M. (2004) Row Configuration and Nitrogen Application for Barley-Pea Intercropping in Montana. Agronomy Journal, 96, 1730-1738. http://dx.doi.org/10.2134/agronj2004.1730

[15] Ross, S.M., King, J.R., O’Donovan, J.T. and Spaner, D. (2004) Forage Potential of Intercropping Berseem Clover with Barley, Oat or Triticale. Agronomy Journal, 96, 1013-1020. http://dx.doi.org/10.2134/agronj2004.1013

[16] Ross, S.M., King, J.R., O’Donovan, J.T. and Spaner, D. (2004) Intercropping Berseem Clover with Barley and Oat Cultivares for Forage. Agronomy Journal, 96, 1719-1729. http://dx.doi.org/10.2134/agronj2004.1719

[17] Karadag, Y. (2004) Forage Yields, Seed Yields and Botanical Compositions of Some Legume-Barley Mixtures under Rainfed Condition in Semi-Arid Regions of Turkey. Asian Journal of Plant Sciences, 3, 295-299. http://dx.doi.org/10.3923/ajps.2004.295.299

[18] Blaser, B.C., Singer, J.W. and Gibson, L.R. (2007) Winter Cereal, Seeding Rate and Intercrop Seeding Rate Effect on Red Clover Yield and Quality. Agronomy Journal, 99, 723-729. http://dx.doi.org/10.2134/agronj2006.0247

[19] El karamany, M.F., Bahr, A.A. and Tawfic, M.M. (2009) Forage Mixture Potential of Berseem Clover (Trifolium alexandrinum) with Triticale (X triticosecale wittmack) or Barley (Hordeum vulgare L.). Bulletin, National Research, 34, 175-185.

[20] El karamany, M.F., Elwea, T.A. and Bakry, B.A. (2012) Effect of Mixture Rates on Forage Mixture of Egyptian Clover (Trifolium alexandrinum L.) with Triticale (X Triticosecale wittmack) under Newly Reclaimed Sandy Soil. Australian Journal of Basic and Applied Sciences, 6, 40-44.

[21] Chapman, H.D. and Pratt, P.F. (1978) Methods of Analysis for Soils, Plant and Water. Division of Agriculture Sciences, University of California, Davis, 162-165.

[22] AOAC (1990) Official Methods of Analysis. 15th Edition, AOAC, Arlington.

[23] Dubois, M., Gilles, K.A., Hamilton, J., Rebers, P.A. and Smith, F. (1956) Colorimetric Method for Determination of Sugar and Related Substances. Analytical Chemistry, 28, 350-356. http://dx.doi.org/10.1021/ac60111a017

[24] Snedecor, G.W. and Cochran, W.G. (1990) Statistical Methods. 8th Edition, Iowa State University Press, Ames.

[25] Gomez, K.A. and Gomez, A.A. (1984) Statistical Procedures for Agriculture Research. 2nd Edition, John Wiley and Sons, New York, 180. 
Scientific Research Publishing (SCIRP) is one of the largest Open Access journal publishers. It is currently publishing more than 200 open access, online, peer-reviewed journals covering a wide range of academic disciplines. SCIRP serves the worldwide academic communities and contributes to the progress and application of science with its publication.

Other selected journals from SCIRP are listed as below. Submit your manuscript to us via either submit@scirp.org or Online Submission Portal.
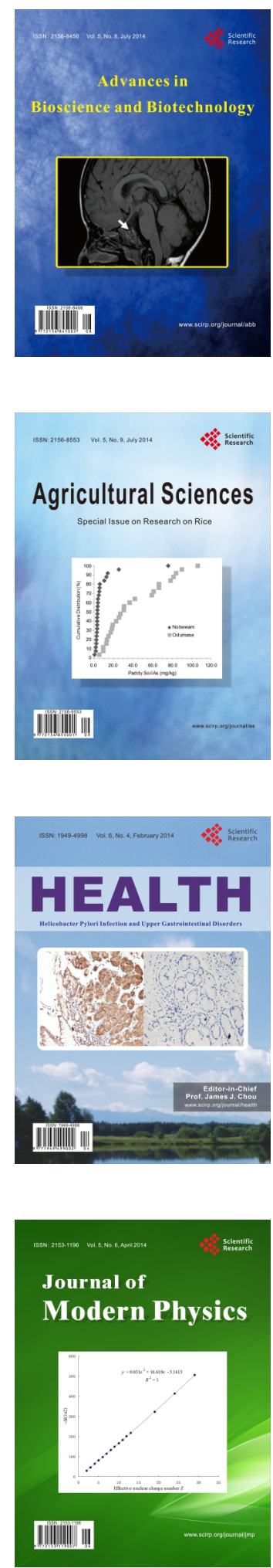
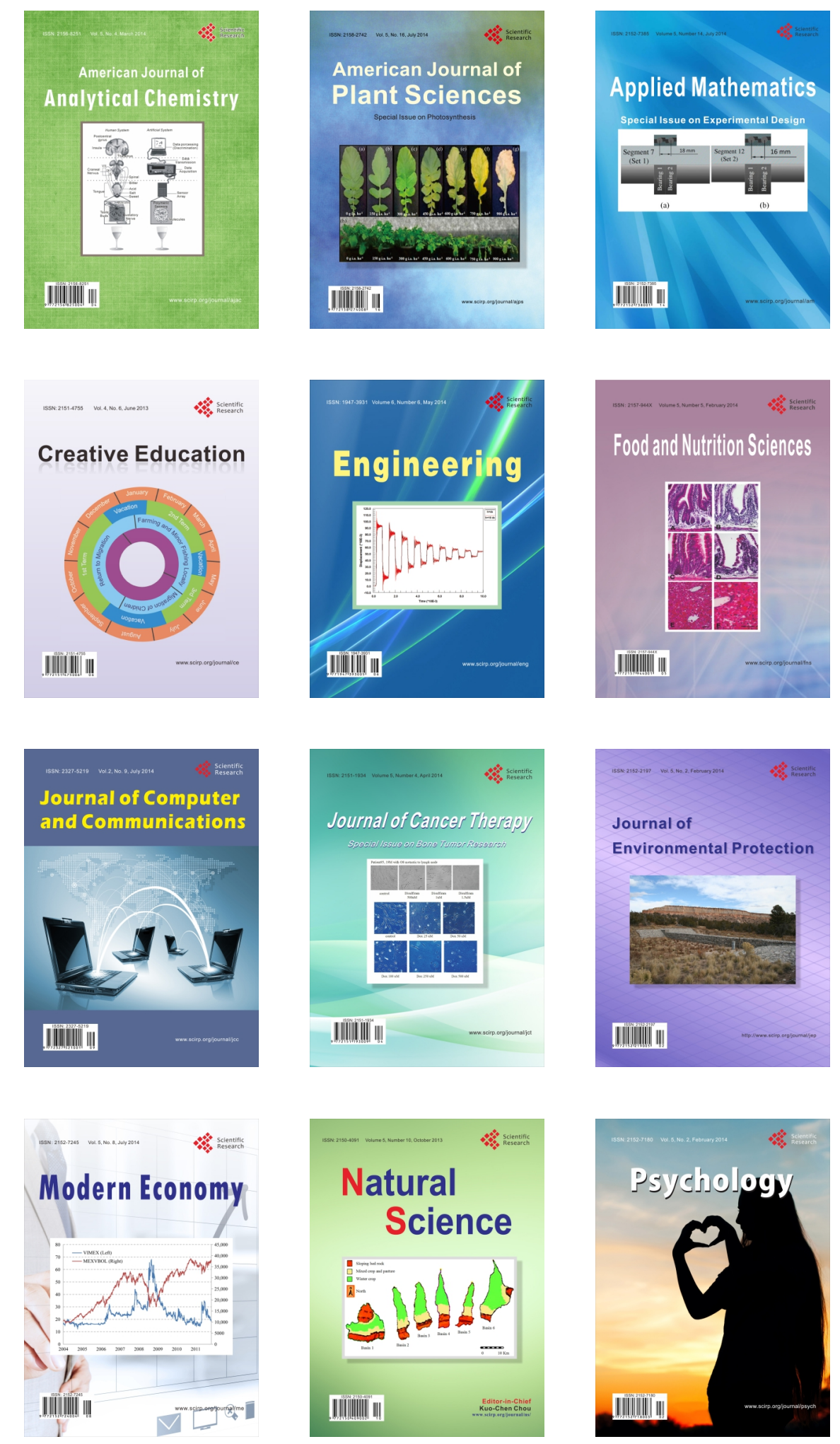